\title{
Digital Television Regulation and its Impact on Indonesia towards Society $\mathbf{5 . 0}$
}

\author{
Arsyad Nurizar \\ ${ }^{1}$ Universitas Airlangga \\ a) arsyadnurizar2@gmail.com
}

DOI: https://doi.org/10.18196/jkm.122039

Article Info

Article history:

Received 21 Apr 2020

Revised 20 Sep 2020

Accepted 24 Nov 2020

\section{ABSTRACT}

The Indonesian government plans to replace all analog television broadcasts with digital television broadcasts. Through digital broadcasting, the public can enjoy television shows with better picture quality and many new services available. The government has actually made regulations relating to digital broadcasting, but the regulations seem to lack a positive response from the public and have been repeatedly sued in court. Until now, the legal basis for the implementation of digital broadcasting in Indonesia is still waiting for the inclusion of the term digitization in regulation at the legal level. The switch to digital broadcasting has left Indonesia unable to enjoy a digital dividend that can be used to provide faster and more extensive broadband internet. This information is important as a form of preparation for entering the era of society 5.0, where access to the internet has an important role to play in the development of science and technological innovation. This study used descriptive qualitative methods to give describe about the urgency of digital broadcasting regulation in Indonesia and its impact on Indonesia related to the preparation of welcoming the era of society 5.0, where technology will get closer to people's lives to solve various social problems.

Keywords: Digital Broadcasting Regulation; Indonesia; Multiplexing; Society 5.0

\begin{abstract}
ABSTRAK
Saat ini pemerintah Indonesia berencana untuk mengganti semua siaran televisi analog dengan siaran televisi digital. Melalui penyiaran digital, masyarakat dapat menikmati acara televisi dengan kualitas gambar yang lebih baik dan banyak layanan baru yang tersedia. Pemerintah sebenarnya telah membuat regulasi berkaitan dengan penyiaran digital, tetapi peraturan tersebut tampaknya kurang mendapat respon positif dari publik dan telah berulang kali digugat di pengadilan. Sehingga saat ini dasar hukum bagi pelaksanaan penyiaran digital di Indonesia masih menunggu pencantuman istilah digitalisasi dalam regulasi setingkat undang-undang. Belum beralihnya ke penyiaran digital membuat Indonesia saat ini belum bisa menikmati dividen digital yang bisa digunakan untuk penyediaan internet broadband yang lebih cepat dan luas. Hal tersebut penting sebagai bentuk persiapan memasuki era society 5.0, dimana akses terhadap internet memiliki peran penting guna pengembangan ilmu pengetahuan dan inovasi teknologi. Penelitian ini menggunakan metode kualitatif deskriptif berusaha memberikan gambaran tentang urgensi regulasi penyiaran digital di Indonesia dan dampaknya bagi Indonesia berkaitan dengan persiapan menyambut era society 5.0, dimana teknologi akan semakin dekat dengan kehidupan masyarakat untuk menyelesaikan berbagai masalah sosial.
\end{abstract}

Kata Kunci: Indonesia; Multiplexing; Regulasi Penyiaran Digital; Society 5.0 


\section{INTRODUCTION}

Television (TV) is a telecommunications technology that has become an essential element in our daily lives. Television exists as a satisfying public need since it presents information and entertainment that can be accessed for free. Most people in Indonesia today still enjoy broadcast shows that are emitted from television stations that use analog technology. Along with the development of technology, the Indonesian government plans to replace all analog television broadcasts with digital television broadcasts. This replacement has been done in stages since 2012 (Y. $\mathrm{Wu}, 2006)$.

Digital television is a type of television that uses digital modulation and compression systems to broadcast video, audio and data signals to television sets. It uses a much higher resolution than the old standard. The most fundamental difference between analog and digital TV broadcasting systems lies in the reception of images via a transmitter. In an analog system, the farther away from the television station, the signal will be weak and image reception becomes poor and shaded, whereas, on a digital system, a clearer picture can be enjoyed to the point where the signal can no longer be received (Sumiaty, 2013). The advantage of using digital television for viewers is watching clear contoured images, with mature colors, and a wider depth of field than televisions with analog systems (Syaidah, 2013). The impact of digital broadcasting for society according to Hutabarat (2014) is that people can enjoy television with better picture quality and there are numerous new services such as messaging, teleconferencing, web surfing, e-commerce, multimedia service, interactive TV, TV on demand.

Digitalization aims to save frequency. This is crucial since frequency is a limited natural resource for the telecommunications world. The spectrum used in television broadcasting has been allocated to several channels in the VHF and UHF bands. Along with spectrum needs and technological developments, spectrum efficiency is one of the important aspects to be used maximally. Therefore, broadcasting technology undergoes a transition process from analog to digital called digital switching or Analog Switch-Off (ASO). The International Telecommunication Union (ITU) stipulates that ASO must be implemented globally before June 17, 2015 (Arsyad, 2012).

The initial plan for the implementation of digital broadcasting in Indonesia began with Simulcast Broadcasting by organizing the airing of analog television broadcasts and digital television broadcasts at the same time. Simulcast broadcasting was tested to the public to compare the quality of digital television with analog so that it can lead the public to choose digital television services with consideration of the better service quality than analog television. Besides, the period of simulcast also aimed to give deadlines to customers before the government would implement the switch off of the analog broadcasting services in 2018 (ATDSI, 2017).

The Indonesian government has prepared regulations to regulate digital television broadcasting. Through the Indonesian Minister of Communication and Information Regulation No. 22/PER/M.Kominfo/11/2011 concerning the Implementation of Digital Terrestrial Television Broadcasting of Unpaid Fixed Reception (free to air), the government was trying to immediately realize the digitalization. However, this desire apparently could not be implemented as in 2012, the Institute of Communication and Media Development (InCODE) took the regulation to the Supreme Court for material testing. The regulation was considered to have no legal basis in Broadcasting Law No. 32 of 2002, because the Broadcasting Law has not laid down the norm for digital broadcasting. As a result, digital TV players do not have a strong legal basis for operating. In 2013, the Supreme Court (MA) canceled the Ministry of Communication and Information Regulation No. 22 of 2011 because it did not have a legal basis and the back of the applicable law. The Supreme Court ruling also overturned the 2018 switch-off clause and considered the division of multiplexing organizers and broadcasters to be invalid since it had no legal basis.

The Supreme Court's decision was answered by the Ministry of Communication and Information by issuing new regulations, namely Indonesian Minister of Communication and Information Regulation No. 32 of 2013 on the Implementation of Digital Television Broadcasting and Multiplexing Broadcasting through Terrestrial Systems which were substantially the same, and only eliminated technical terms that were not contained in the Broadcasting Law. However, these regulations also continue to get a rejection from various parties, so that until now the legal basis for the implementation of digital television is still unclear. The digital television implementation is still waiting for the Broadcasting Law revision which provides a strong legal basis, especially relating to 
the implementation of Analog Switch-Off (ASO). This is truly unfortunate because various advantages as a result of the digital television application cannot be enjoyed by Indonesian society.

This research aims to find out the impact of the delay in the digital television application in Indonesia for welcoming the era of society 5.0. In order to obtain comparison and reference materials, the researcher listed the results of previous studies related to the topic of the research. Research conducted by Vinna (2015) with the research title "Menyoal Regulasi Penyiaran Digital (Studi terhadap Kepentingan Publik dalam Regulasi Televisi Digital di Indonesia)" states that digital broadcasting regulations show that the government tends to side with capital interests in determining multiplex managers. Then, in terms of public interest, regulation also does not reflect the government's efforts to put the public interest above the interests of the market. Furthermore, the research conducted by Budiman (2015) with the research title "Model management of Broadcasting Digitization in Indonesia" states that the migration of the use of analog broadcasting technology to broadcasting with digital technology, requires legal certainty with the regulatory arrangements in the law considering that the radio frequency spectrum is a limited resource whose use is aimed at the welfare of the public and the model of managing the digitization of broadcasting should be directed to obtain the maximum and clear digital dividend and be responsible in its utilization. Then the research conducted by Ervan (2019) with the research title "Digital Broadcasting Regulation: State Role Dynamics, Private Roles, and Benefits for the People" states that the utilization of digital technology in the field of broadcasting through the revision of the Law can be a solution for frequency limitation as well as efficiency of its use for more diverse broadcasting providers (diversity of ownership).

Through this research, the researchers are trying to describe and complete research related to digital broadcasting, especially the urgency of regulation so that it can be ratified immediately given its huge impact as a form of preparation for the era of society 5.0. Society 5.0 promotes the concept of a revolution in society that utilizes technology to make life easier so that future services will emerge to accommodate this need. Several sectors of work and needs began to incorporate digitalization using Artificial Intelligence, Big Data, and the Internet of Things (Al Faruqi, 2019). This is undoubtedly a challenge for Indonesia to provide information technology services especially related to faster and more equitable internet access in Indonesia which one of them can be fulfilled through digital dividends from the migration to digital broadcasting. Based on this, it is interesting to discuss how the complexity of digital broadcasting regulation is in Indonesia and its impact on Indonesia to enter the era of society 5.0.

\section{METHODS}

This study used a qualitative approach. This approach was carried out to understand the phenomena about what is experienced by research subjects holistically and by descriptions in the form of words and language, in a special natural context and by utilizing various scientific methods (Moloeng, 2002). This research specifically used descriptive research to provide a detailed description of a specific phenomenon. Descriptive research does not carry out manipulation or alteration on the independent variables but describes a condition as is. The depiction of conditions can be individual or use numbers (Sukmadinata, 2006). The focus of this research is the urgency of digital broadcasting regulation and its impact on Indonesia entering society 5.0, so that a clear understanding of the phenomenon can be obtained. Data collection techniques are carried out by researcher by conducting an interview to speaker relevant to the topic of research, researcher conduct interview with Mr. Haryu Kresno who currently serves as Policy Analyst and Sub Coordinator of Broadcasting Technology Feasibility at the Ministry of Communication and Informatics. In addition, the researcher also conducted Data collection techniques through a literature study. Literature study conducted by the researcher by reviewing books, journals and regulations related to research problems. The study was conducted by the researcher between June 2020 and August 2020. Then from the research data, the researcher conducted qualitative data analysis activities in the form of: data reduction, data presentation and withdrawal of conclusions. 


\section{RESULT AND DISCUSSION}

\section{The Complexity of Digital Broadcasting Regulations in Indonesia}

The Indonesian state, an archipelago of thousands of islands, with the inclusion of digital broadcasting, is certainly good news for the Indonesian citizens, considering there are still some regions in Indonesia that have not been able to enjoy television shows with good quality because of the long distance from the transmitting station. Because of the analog systems used today and the far distance of the television stations, the signal will be weak and the image reception becomes poor and shaded. Whereas, if later use a digital system is used, clear image broadcasts can be enjoyed to the point where the signal can no longer be received so that the public's right to obtain uninterrupted information can be fulfilled.

Digital television is a type of television that uses digital modulation and compression systems to broadcast video, audio and data signals to television sets. The regulation on digital broadcasting in Indonesia has been started since 2007 through the Regulation of Ministry of Communication and Informatics of Indonesia No. 07/PER/M.KOMINFO/3/2007 on Digital Terrestrial Television Broadcasting Standards in Indonesia. Then proceed with Indonesian Minister of Communication and Information Regulation No. 39/PER/M.KOMINFO/10/2009 on the Basic Framework for the Implementation of Digital Terrestrial Television Broadcasting of Unpaid Fixed Reception (free to air) and the Regulation of Ministry of Communication and Informatics of Indonesia No. 21/PER/M. KOMINFO/4/2009 on Digital Broadcasting Standards for Radio Broadcasting on Very HighFrequency Bands (VHF) in Indonesia.

Then followed by Indonesian Minister of Communication and Information Regulation No. 22/PER/M.KOMINFO/11/2011 on the Implementation of Digital Terrestrial Television Broadcasting of Unpaid Fixed Reception (free to air) (Minister of Communication and Information, 2012). The Regulation of the Regulation of Ministry of Communication and Informatics of Indonesia No. 22/PER/M.KOMINFO/11/2011 provides an explanation that the purpose of immediately switching to digital television includes:

1. receiving the quality of television broadcast program reception;

2. giving more broadcast program options to the public;

3. accelerating the development of healthy television media in Indonesia;

4. grow content, software and hardware industries related to digital terrestrial television broadcasting, unpaid reception; and

5. improve the efficiency of radio frequency spectrum utilization for broadcasting operations.

Through the Regulation of Ministry of Communication and Informatics of Indonesia No. 05/PER/M.KOMINFO/2/2012 on Digital Terrestrial Television Broadcasting Standards of Unpaid Fixed Reception (free to air) has determined that Indonesia will use digital television broadcasting standard that is Digital Video Broadcasting - Second Generation Terrestrial (DVB-T2). The standard is the latest from the European standard which allows broadcasting 12 Standard Definition (SD) programs in one frequency channel. This is certainly an excellent first step for Indonesia where with digital broadcasting people can save a lot of frequencies compared to analog television in which one channel can only be filled with one broadcast program.

In the implementation the Digital Terrestrial Television Broadcasting of Unpaid Fixed Reception (free to air) which is stipulated in the Regulation of Ministry of Communication and Informatics No. 22/PER/M.KOMINFO/11/2011 mentioned that there are two kinds of organizing institutions as follows:

a. Broadcast Program Provider of Broadcasting Institutions, hereinafter referred to as LPPPS, is an institution that manages broadcast programs to be aired to the public in a service zone through broadcast channels or slots in radio frequency channels;

b. Multiplexing Broadcasting Provider of Broadcasting Institutions, hereinafter referred to as LPPPM, is an institution that distributes several broadcast programs through a multiplex device and transmission device to the public in a service zone.

The LPPPS will be implemented by three institutions, namely the Public Broadcasting Institution TVRI, Private Broadcasting Institution, and Community Broadcasting Institution. Then, the LPPPM will be carried out by the Public Broadcasting Institution TVRI and Private Broadcasting 
Institutions. The division of institutions in this regulation did not receive a positive response from the society as it was not following the initial idea of the implementation of digital broadcasting that is LPPPM only holds rights to frequencies, while LPPPS is the provider of broadcast content. Every television station that will broadcast in an area must lease a channel from LPPPM operating in that area. However, according to the Regulation of Ministry of Communication and Informatics No. 22/PER/M.KOMINFO/11/2011, LPPPM was given a double room as the holder of frequency rights and broadcast content providers. While LPPPS may not necessarily be the right holder for frequencies (Febriyan, 2015).

In 2012, the Institute of Communication and Media Development (InCODE) took the regulation to the Supreme Court for material testing. The regulation was considered to have no legal basis in Broadcasting Law No. 32 of 2002 because the Broadcasting Law has not laid down the norm for digital broadcasting. Besides, the digital TV frequency tender to Private LPPPM was considered to trigger a monopoly and could make local TV did not get digital terrestrial channels, and there was no clarity for community broadcasting institution. So that in 2013, the Supreme Court (MA) canceled the Minister of Communication and Information Regulation No. 22/PER/M.KOMINFO/11/2011 because it did not have a legal basis and the background of the applicable law (Indonesian Broadcasting Commission, 2012). According to the statement from Mr. Haryu, the Regulation of the Minister of Communication and Information was cancelled because it regulated the implementation date of ASO which was considered to have a great impact on the community so that the regulation must go through the law which was the revision of the broadcasting law.

This then caused another problem because even though the Regulation of Ministry of was being sued, on September 27, 2012, the government still signed 23 decisions regarding the determination of the results of the LPPPM auction which would operate in seven provinces. Thus, the cancellation gave an impact on LPPPM as the digital broadcasting provider did not have a strong legal basis for operating. To overcome this, the Supreme Court's ruling was answered by the Ministry of Communication and Information by issuing new regulations, namely the Regulation of Ministry of No. 22/PER/M.Kominfo/11/2011 No. 32 of 2013 on the Implementation of Digital Television Broadcasting and Multiplexing Broadcasting Through Terrestrial Systems. Even though the number and year were substantially different, it turned out that the contents of the new ministerial regulation were nearly typical with those that had been canceled and only eliminated technical terms that were not contained in the Broadcasting Law. the Regulation of Ministry of also insisted to recognize the results of the multiplexing auction that had been previously determined, because they thought that the Supreme Court's decision on it was not retroactive. It means that the results of the LPPPM selection that have been held are still valid.

Then it triggered the Indonesian Network TV Association (ATVJI) to file a lawsuit again to the Ministry of Communication and Information to cancel the results of the auction and the Supreme Court granted it. The Ministry of Communication and Information must accept the defeat at the Supreme Court even though it has gone through an appeal process. With such a long and complicated journey of the broadcasting digital regulation, for the moment the only way expected is to provide certainty of law and the power of the legality of the digital broadcasting in Indonesia by referring to the inclusion of digitalization in the revision of Broadcasting Law No. 32, 2002 as a solution. However, it was not easy since until now the Broadcasting Law revision has not found a bright spot and lacked a serious response from the legislature. According to Mr. Haryu's description, the Ministry of Communication and Information is currently looking for other alternatives to overcome this, namely to trying to make the term digitization that can be included in the discussion of the draft of Omnibus Law Cipta Kerja. This is possible because according to the Ministry of Communication and Information, it is by switching to digital broadcasting. Indonesia can get digital dividends that can encourage the emergence of new businesses in the digital field and certainly create new jobs later.

\section{The Urgency of Digital Broadcasting Regulations in Welcoming the Society 5.0}

The Society 5.0 term first appeared in Japan in 2016 and has spread and its basic concepts continue to be shaped. The concept was created as a development of the industrial revolution 4.0 which was considered to have the potential to decrease human role. Society 5.0 is a term used in the Fifth Science and Technology Basic Plan, which is reviewed by the Japanese Government's Board of Science, Technology, and Innovation. Society 5.0 can be defined as an "intelligent society", which 
truly integrates the physical world and cyberspace. Although focused on humanity, 5.0 refers to new types of society; innovation in science and technology occupies a prominent place to balance social problems that need to be solved while ensuring economic development (Suwandi, 2019).

Society 5.0 in technological development is more directed at the order of social life, where every challenge can be solved through a combination of innovation of the various elements contained in the industrial revolution 4.0. The new value that exists in society 5.0 is created through innovations that can eliminate regional, age, gender, and language disparities and enable the provision of products and services that are finely designed for a variety of individual and latent needs. In this way, it will be possible to reach a society that can promote economic development and find solutions to social problems (Raharja, 2019).

Regarding preparations for welcoming the society 5.0, Indonesia must have prepared various kinds of technological infrastructure. One of them is to prepare adequate network frequencies for technological development, especially technology that uses the internet network. This is to compensate for the emergence of various technologies especially related to information technology namely the emergence of various new media that adopt internet technology that allows the process of sending and receiving messages to be more time-saving, easy and effective (Darwadi, 2017). The use of digital broadcasting technology will certainly be able to save a lot of frequencies. By saving the country's frequency, the people can get digital dividends. Digital dividends can be utilized to the maximum for the management of the internet for the benefit of broadcasting and telecommunications. In particular, the use of digital dividends is for the benefit of telecommunications for the public. Digital dividends can also be done to improve electronic information networks for educational and ebusiness purposes (Budiman, 2015). The Ministry of Communication and Information itself states that the dividend will be used for the development of mobile broadband with distant reach and capacity or high speed of $5 \mathrm{G}$ technology. High-speed internet technology is of course very important entering the era of society 5.0 to meet the public's need for information.

Analog TV currently utilizes a sizeable frequency resource of $700 \mathrm{MHz}$. According to a statement from Mr. Haryu, if the space has been switched from analog to digital, there will be an empty space of $112 \mathrm{MHz}$. Later, the empty space will be auctioned to telecommunication operators with the obligation that they must participate in building telecommunication infrastructure in the $3 \mathrm{~T}$ region (disadvantaged, leading and outer areas in Indonesia), as well as various facilities related to education and disaster management. This is certainly important being given with the uneven development in our country in preparation for the society 5.0 era.

However, it seems that the benefits of the transition to digital television are still just an expectation because until now it is unclear when the transition will be done. Serious intentions from the government and legislators are needed to immediately work on the revision of Broadcasting Law No. 32 of 2002 as a legal basis for the implementation of digital television. This needs to be done immediately because Indonesia will soon enter the era of society 5.0, an era where people's lives will be closer to technology. In the era of society 5.0, the role of technology is much improved so that it could facilitate humans in various aspects. Technological advances, especially communication, will have tremendous consequences for people's lives in various fields ranging from culture, politics and especially economics because it has the potential to increase people's productivity in work and also help the community economy (Murad Lubis, 2015). In order to enter the era of society 5.0, the role of high-speed internet is certainly necessary in order to maximize various innovations of artificial intelligence (AI) based on technology that will develop later to meet various needs of society.

Indonesia is one of the two countries in Southeast Asia whose broadcasting system has not yet migrated to digital. Whereas in the ITU agreement, the UN agency in charge of technology demanded migration had to be carried out in 2015. Indonesia can be technologically isolated if it does not immediately implement digitization which will certainly harm the community (Budiman, 2015). The absence of migration from analog to digital can also have an impact on the disruption of the signal network on mobile phones due to the scrambling of the network with internet users whose numbers continue to swell every year. Also, the decline in the quality of internet services can occur due to an increase in mobile internet traffic that cannot be matched by the availability of ideal frequencies. The frequency that is needed and has been used by many countries is $700 \mathrm{MHz}$ because it is the most ideal frequency for deploying mobile broadband with a wide range and high capacity or speed. But in Indonesia, that frequency cannot be used yet because it is still used for broadcasting Free to Air TV which still uses analog technology. The government needs to see that the frequency is a limited amount of natural resources. Therefore, at there has arisen a problem related to the number of parties 
who want and can hold TV broadcasts but cannot get new permission for analog broadcasting, because it is constrained by frequency slots that are no longer available (Ismail, 2019). Therefore, delaying the implementation of digital broadcasting will only continue to benefit private television station owners who have already received frequency slots, while new television stations can only bite their fingers because they do not get frequency slots.

During the process of making digital broadcasting regulations, the government must be able to accomodate the aspirations of the society to create fair and unfavorable regulations for either party. The involvement of society's aspirations in drafting regulations is very important so that when the regulation has been legitimated there will not be any commotion in the community which is contrary to the regulations made. If we look at the implementation of the existing regulations, related to the implementation of multiplexing operator auctions, the list of multiplexing operator competition winners is dominated by media conglomerates. This is because the existing regulations require that only the existing institutions with broadcasting licenses can participate in the auction. The list of multiplexing operator competition winners organized by the Ministry of Communication and Information is presented in Table I (Rahayu, 2016).

Table 1. List of Multiplexing Operator Competition Winners

(Source: Ministry of Communication and Information 2012 2013)

\begin{tabular}{|c|c|c|c|c|c|c|c|}
\hline $\begin{array}{l}\text { Multiplexing } \\
\text { Zones }\end{array}$ & TVRI & $\begin{array}{l}\text { MNC } \\
\text { Group }\end{array}$ & $\begin{array}{l}\text { Trans } \\
\text { Corp }\end{array}$ & $\begin{array}{l}\text { EMTek } \\
\text { Group }\end{array}$ & $\begin{array}{l}\text { Viva } \\
\text { Group }\end{array}$ & $\begin{array}{l}\text { Media } \\
\text { Group }\end{array}$ & BS TV \\
\hline Zone 1 & 9 & 9 & 9 & 9 & 9 & 9 & \\
\hline Zone 2 & 9 & & & & & & \\
\hline Zone 3 & 9 & & & & & & \\
\hline Zone 4 & 9 & & 9 & 9 & 9 & 9 & 9 \\
\hline Zone 5 & 9 & 9 & 9 & 9 & 9 & 9 & \\
\hline Zone 6 & 9 & 9 & 9 & 9 & 9 & 9 & \\
\hline Zone 7 & 9 & 9 & 9 & 9 & 9 & 9 & \\
\hline Zone 8 & 9 & & & & & & \\
\hline Zone 9 & 9 & & & & & & \\
\hline Zone 10 & 9 & & & & & & \\
\hline Zone 11 & 9 & & & & & & \\
\hline Zone 12 & 9 & & & & & & \\
\hline Zone 13 & 9 & & & & & & \\
\hline Zone 14 & 9 & 9 & 9 & 9 & 9 & 9 & \\
\hline Zone 15 & 9 & 9 & 9 & 9 & & & \\
\hline Total & 135 & 54 & 63 & 63 & 54 & 54 & 9 \\
\hline
\end{tabular}

Based on Table 1, it is known that private television owned by media conglomerates tended to dominate the list of multiplexing operator competition winners as multiplexing broadcasters and only one local television station won the tender, namely PT. Banten Sinar Dunia Televisi (BSTV). Therefore, it is not surprising that the regulations of broadcasting that have been made before are considered detrimental to local television and the community as well as being vulnerable to triggering a monopoly on new models by media conglomerates. Multiplexing broadcasters who can also act as providers of broadcast programs are feared to be detrimental to local television and the community. The current regulation is considered less adopting the public interest because it is more inclined to the market and broadcasting institutions that have been there before (Yusuf, 2014). Therefore, the hope for the diversity of content and ownership is feared not to happen in the era of digital broadcasting later, because it will still be controlled by the big television industry (Prabowo, 2012). 
Based on that, the Government should immediately reform, making the regulation of digital broadcasting that can be accepted by all parties must be the government priority, so that people can enjoy television with better picture quality and the efficiency of frequency can be used to provide qualified telecommunications network and internet for the society. Entering the Society 5.0, internet access plays an essential role in improving mobility in health, well-being, education, and social care in order to reduce the gap between urban and rural areas. Economic benefits can also be felt from the spectrum allocation of digital dividends for cellular operators that will provide enormous economic impetus, innovations, the formation of new jobs, productivity and a more competitive environment (Alaydrus, 2017). The government should see that there is a major threat behind the unperturbed migration to digital systems, because it can have an impact on the disruption of signal networks on mobile phones due to the scramble of internet users whose numbers continue to increase every year (Akbar, 2017). The increase in the number of internet users also led to a decrease in the quality of internet services due to an increase in mobile internet traffic that could not be offset by the availability of ideal frequencies (Hidayat, 2020). According to Mr. Haryu's description, this is because the 700 $\mathrm{MHz}$ frequency band which is the ideal frequency band (has a wider and faster coverage band) for broadband internet access service is still being by analog TV services stretching from a range of 478 $\mathrm{MHz}$ to $806 \mathrm{MHz}$. Thus, the slow migration to digital TV, causes making bandwidth rations for mobile phones and internet signals need to be shared with analog TV services. In addition to this, according to Mr. Haryu, Indonesia is also threatened by international lawsuits from neighboring countries such as Malaysia and Singapore. This is because the neighboring countries already implemented ASO, but have not been able to fully utilize digital dividends from the transition to digital broadcasting. The case occurs because Indonesia has not performed ASO which causes frequency disruption to countries bordering Indonesia which have implemented ASO.

The government should also see that there is a huge threat behind the delay of migration to the digital system because it can have an impact on the disruption of the signal network on mobile phones which is getting weaker due to scrambling networks with internet users whose numbers continue to increase every year. The increase in the number of internet users causes a reduction in internet service quality due to an escalation in mobile internet traffic that cannot be matched by the availability of ideal frequencies (Hidayat, 2020).

The government and members of the council should jointly develop regulations that can accommodate the aspirations of media activists and society so that the realization of broadcast migration from analog to digital can be carried out soon. The government also needs to see that an indicator of the success of a technological leap is the welfare of the people, can be enjoyed by all, and there is no monopoly. It is expected that the migration process of analog TV to digital can provide numerous benefits for all levels of society and does not only benefit either party. Welcoming the era of society 5.0 migration to digital broadcasting is a necessity so that the digital dividend of the implementation of the migration can be immediately enjoyed by the people of Indonesia. Digital dividend planned to be allocated for broadband internet is necessary given an increasing number of internet users while frequency capacity is limited. Therefore, the provision of frequency for broadband internet access is necessary, this is given the very important role of internet welcoming the society 5.0 era for the development of science and technological innovation.

\section{CONCLUSION}

In this current global condition, the implementation of Digital TV Broadcasting has been carried out almost all over the world and even some countries have implemented ASO (Analog Switch Off). Meanwhile, the initial plan for the commencement of ASO in the Republic of Indonesia was in 2012 following the government's road map to be able to meet ASO-free globally determined by the International Telecommunication Union (ITU) before June 17, 2015. Until today, Indonesia has not been able to implement digital broadcasting because until now the legal basis for the implementation of digital broadcasting has not been resolved. Furthermore, there is a huge threat behind the delay of migration to the digital system, because it can have an impact on the disruption of signal network on mobile phones due to the scramble of the network with internet users whose number continues to increase every year. In addition, the decline in internet service quality can also occur due to an increase in mobile internet traffic that cannot be matched by the availability of ideal frequencies. The most ideal frequency that is needed for deploying mobile broadband with a wide range and high 
capacity or speed is $700 \mathrm{MHz}$. However, in Indonesia, that frequency cannot be used yet because it is still used for broadcasting which still uses analog technology. The implementation of digital broadcasting must be carried out immediately so that our country does not get left behind other countries. Through digital broadcasting, the public can enjoy more diverse channels with clearer image quality. In addition, the digital dividend that becomes the biggest incentive from digital television migration is the provision of faster and wider broadband internet can be realized. This is important as a form of preparation for entering the era of society 5.0 where access to the internet has an important role to play in the development of science and technology-based innovation, especially Artificial Intelligence (AI) that is now increasingly popular to use. Therefore, the government together with the legislature must immediately ratify the regulation as the basis for the implementation of ASO in Indonesia. The government should also continue to encourage broadcasters to broadcast simulcast. This is necessary so that it will not take long for broadcasters and public do not take long to adapt when ASO is been implemented.

\section{REFERENCES}

Alaydrus, Mudrik. (2017). Digital Dividend pada Migrasi TV Analog ke TV Digital- Prospek dan Dilema. Jakarta: Universitas Mercu Buana.

Akbar, Caesar, \& Nur Hidayat. (2017, September 15). Sinyal HP Kecil Akibat Migrasi TV Digital Lambat? Ini Kata BRTI. Retrieved from https://bisnis.tempo.co/read/909493/sinyal-hp-kecilakibat-migrasi-tv-digital-lambat-ini-kata-brti/full\&view=ok.

Al Faruqi, Umar. (2019). Future Service in Industry 5.0: Survey Paper, Jurnal Sistem. Cerdas, 2 (1), 67-79.

Arsyad, and R. A. Wahab. (2012). Kesiapan Penyelenggara Siaran TV Swasta Di Sulawesi Utara dalam Menghadapi Migrasi Siaran TV Analog Ke Digital. Jurnal Penelitian Komunikasi dan Opini Publik, 16 (3), 195-213.

Asosiasi Televisi Siaran Digital Indonesia (ATDSI). (2017). Masukan Asosiasi Televisi Siaran Digital Indonesia (ATDSI) Kepada Badan Legilasi (BALEG) DPR Terkait Harmonisasi RUU Penyiaran Inisiatif DPR, 5, 1-13.

Budiman, Ahmad. (2015). Model Pengelolaan Digitalisasi Penyiaran di Indonesia. Politica, 6 (2), 109-121.

Darwadi, MS. (2017). Media Baru Sebagai Informasi Budaya Global. Jurnal Komunikator, 9 (1), 45.

Febriyan. (2015, March 16). Kocok Ulang Kanal Digital. Retrieved from https://majalah.tempo.co/read/hukum/147721/kocok-ulang-kanal-digital?.

Hidayat, Nur, and Caesar Akbar. (2017, September 14). Dua Tahun Lagi Sinyal Ponsel Bakal Kian Sulit Didapat. Retrieved from https://bisnis.tempo.co/read/909142/dua-tahun-lagi-sinyalponsel-bakal-kian-sulit-didapat/full\&view=ok.

Hutabarat, Daniel P. (2014). Tinjauan Terhadap Model Bisnis Penyelenggaraan Penyiaran TV Digital. ComTech, 5 (1), 485-494.

Indonesian Broadcasting Commission. (2012, July 26). Polemik Televisi Digital, PERMEN Kominfo Digugat Ke MA. Retrieved from http://www.kpi.go.id/index.php/id/umum/30676-polemiktelevisi-digital-permen-kominfo-digugat-ke-ma.

Ismail, Ervan, et al. (2019). Regulasi Penyiaran Digital: Dinamika Peran Negara, Peran Swasta, dan Manfaat bagi Rakyat. Jurnal Komunikasi Pembangunan, 17 (2), 124-145.

Lubis, Murad. (2015). Implementasi Pembangunan Infrastruktur dan Teknologi Komunikasi untuk Pengembangan Masyarakat. Jurnal Komunikator, 7 (1), 61- 62.

Moloeng, Lexy J. (2002). Metodologi Penelitian Kualitatif. Bandung : PT. Remaja Rosdakarya.

Prabowo, Agung. (2012). Era Penyiaran Digital : Pengembangan atau Pemberangusan TV Lokal dan TV Komunitas?. Komunikasi, 1 (4), 312.

Raharja, Handy Yoga. (2019). Relevansi Pancasila Era Industry 4.0 dan Society 5.0 di Pendidikan Tinggi Vokasi. Journal of Digital Education, Communication, and Arts, 2 (1), 11-20.

Rahayu, T.P. (2016). Indonesia's digital television migration: Controlling Multiplexing, tackling competition, Intellect, 7 (2), 233-252.

Sukmadinata, \& N. Syaodih (2006). Metode Penelitian Pendidikan. Bandung: PT. Remaja Rosdakarya.

Sumiaty, Noneng. (2013). Menyambut Era Televisi Digital. Pros. Seminar Penyiaran di Era Digital, 
91-102.

Sutanto, Vinna Waty, \& Salim Alatas. (2015). Menyoal Regulasi Penyiaran Digital (Studi terhadap Kepentingan Publik dalam Regulasi Televisi Digital di Indonesia). Avant Garde, 3 (2), 248.

Suwandi, Sarwiji. (2019). Bahasa, Sastra, dan Pembelajarannya dalam Prespektif Masyarakat 5.0. Yogyakarta: Kepel Press.

Syaidah. (2013). Kebijakan Migrasi Siaran Televisi Analog ke Televisi Digital. Pros. Seminar Penyiaran di Era Digita, 103-110.

Wu, Y., et al. (2006). "Overview of Digital Television Development Worldwide". Proceedings of the IEEE, 94 (1), 8-21.

Yusuf, Iwan Awaludin. (2014). Digitalisasi Televisi di Indonesia: Peluang dan Ancaman terhadap Demokrasi," Paper presented at the National Seminar of Communication, 169-175. 